\title{
Re-Examining the Protection of the Environment under the 1999 Constitution and International Instruments
}

\author{
Dr Linus O. Nwauzi ${ }^{1}$ Claribel Diebo Fab-Eme ${ }^{2}$ \\ 1. LLB, LLM, BL, PhD (India), Senior Lecturer and Head, Department of Business Law, Faculty of Law, \\ Rivers State University, Port Harcourt, Nigeria. \\ 2. Lecturer, Department of Private and Property, Faculty of Law, Rivers State University, Nkpolu- \\ Oroworukwo, Port Harcourt
}

\begin{abstract}
The protection of the environment is now of both local and international concern. The Constitution of the Federal Republic of Nigeria 1999 provides for environmental matters in Section 20 as one of the Fundamental Objectives and Directive Principles of State Policy contained in Chapter II of the said Constitution. This is the first time environmental issues are captured in the Constitution of Nigeria. In addition, the Constitution also places the subject-matter on the exclusive legislative list by virtue of Item 60(a) which empowers the National Assembly to make laws for establishment and regulation of authorities for the Federation or any part thereof to promote and enforce the observance of the Fundamental Objectives and Directive Principles of State Policy in the Constitution. The Constitution contains nothing else on the protection of the environment despite the importance of environment today in Nigeria and world over. Pursuant to the said Section of the Constitution and the powers conferred on the National Assembly under the exclusive legislative list, the National Assembly has enacted laws aimed at protecting the environment; prominent among these laws are National Environmental Standards and Regulation Enforcement Agency (Establishment) Act, 2007 (NESREA Act) and the National Oil Spill Detection and Response Agency (Establishment) Act 2006 (NOSDRA Act). This paper examines the said constitutional provisions and other legislations on environment and the attitude of the Courts in the interpretation of that Section as it affects individual rights of the citizens to the environment. The paper also examines the attitude of the international community towards the protection of the environment especially the instruments and treaties made towards protecting the environment. The paper concludes that environment is of great importance both to the present and future generation; therefore every effort should be made by all, towards its preservation, both at domestic and international level.
\end{abstract}

Keywords: Constitution, Environment, Legislations, International Instruments, Directive Principles.

DOI: $10.7176 / \mathrm{JLPG} / 89-27$

Publication date:September $30^{\text {th }} 2019$

\section{Introduction}

There is no doubt that there is growing concern about the environment and how it is to be preserved and protected not just for the interest of those who are alive, work and exploit it today but for generations unborn. The concern represents an inter-generational solidarity and an acknowledgment of a debt to humanity and the world of tomorrow with respect to the use of the environment. ${ }^{1}$ Environment affects and impacts on the life, health, private life, and property of individuals besides the collective impact on the society. In Nigeria the issue of protection and preservation of the environment is even of greater importance considering the extra burden given to the environment as a result of oil exploration and exploitation especially in the Niger Delta. In recent times Port Harcourt and Rivers State in general have been experiencing unprecedented pollution of environment by what is called soot. This underscores the need for the protection of environment in Nigeria.

\subsection{Conceptual Analysis}

The term environment can simply be regarded as the entire life we live, for without environment there is no life at all. It refers to the physical matters; the air, the sea, the land, natural resources, flora and fauna and the cultural heritage:- like items of archaeological, historical, artistic and scientific interest. It can also be a description of a non-physical sense of surroundings and perceptions. ${ }^{2}$ According to R. Ramanatha Aiyar's Concise Law Dictionary, 'Environment includes water, air and land and the interrelationship which exists among and between water, air and land, and human beings, other living creatures, plants, micro-organisms and property.'3

Ugba U. Ndukwe: 'Can Environmental Laws protect the Nigerian Environment' in M. O. Unegbu and I. Okoronye (eds) Legal Developments in the New World Order (Jite Books Port Harcourt Nigeria 2009) 446.

$2 \quad$ M. Dixon and M. Robert, Cases and Materials On International Law (2 $2^{\text {nd }}$ edn 1995) 521.

Shakel Ahmad Khan (ed), P. Ramanatha Aiyar's Concise Law Dictionary, (4 ${ }^{\text {th }} \mathrm{edn}$, Lexis Nexis Butterworths Wadhwa Nagpur 2012) 437. 
The International Convention on Civil Liability for Environmental Damage (ICCLED) also included in its definition of environment-, natural resources - both biotic and abiotic thus covering not only the natural environment but also the manmade landscape buildings and objects that form part of man's cultural heritage. ${ }^{1}$ Lang also defines environment as encompassing air, water, flora, fauna, and other manmade features that make up our surrounding. ${ }^{2}$ The environment has also been defined as the material and spiritual influences which affect the growth, development and existence of a living being. ${ }^{3}$ Black's Law Dictionary defines environment as 'the totality of physical, economic, cultural, aesthetic and social circumstances and factors which surround and affect the desirability and value of property and which also affect the quality of people's lives. The surrounding conditions, influences or forces which influence or modify. ${ }^{4}$

According to Fagbohun, 'in its most general sense, environment refers to our surroundings. It is often understood to include not only land, air and water, but also the building environment and the condition of the local neigbourhood. In some quarters, it has been described as the whole sum of the surrounding external conditions within which an organism, a community, or an object exists...' ${ }^{5}$ Section 37 of the National Environmental Standards and Regulation Enforcement Agency (Establishment) Act, 2007 defines environment to include water, air, land and all plants and human beings or animals living therein and the inter-relationships which exist among these or any of them. ${ }^{6}$ By these definitions, environment is regarded as a State of affairs of Nature viewed holistically and based upon the milieu of man in his natural habitat. ${ }^{7}$ It is axiomatic therefore to state that environment is life in its totality.

\section{Constitutional Provisions on the Protection of the Environment in Nigeria}

The issue of the protection of the environment came for the first time to be given Constitutional recognition under the 1999 Constitution of Nigeria. It is of common knowledge that the previous constitutions of Nigeria viz. the 1979 Constitution, Republican Constitution of 1963, Independence Constitution of 1960, Lyttleton Constitution of 1954, Macpherson Constitution of 1951, the Richard Constitution of 1946 and the Clifford Constitution of 1922 never provided for environment in any form-either as a fundamental right or a directive principle.

The incorporation of Environmental Objectives into Chapter II of the 1999 Constitution made the Federal Government to put in place a very comprehensive Act that will regulate and enforce environmental matters in Nigeria. In 2007 the National Assembly enacted the NESREA Act. ${ }^{8}$ This Act establishes a body known as National Environmental Standards and Regulations Enforcement Agency (NESREA). The said Agency is a body corporate with perpetual succession and a common seal. It can sue and be sued in its name. ${ }^{9}$ The objectives for the establishment of the Agency include the protection and development of the environment, biodiversity conservation and sustainable development of Nigeria's Natural resources in general and environmental technology, including coordination and liaison with relevant stakeholders within and outside Nigeria on matters of enforcement of environmental standards, regulations, rules, laws, policies and guidelines. ${ }^{10}$

The Agency was given wide powers and functions under Part II of the Act. The functions of the Agency include enforcing compliance with relevant legislation and guidelines, coordinating and liaising with stakeholders on matters pertaining to the environment, enforcing compliance with international instruments on the environment, and carrying out public enlightenment on environmental issues. ${ }^{11}$ NESREA is also charged with the responsibility of enforcing environment control measures through registration, licensing and permitting system other than in the oil and gas sector. ${ }^{12}$ Furthermore, this agency is responsible for enforcing compliance with laws on safe use of pesticides; and handling of hazardous wastes other than in the oil and gas sector

\footnotetext{
E. E. Okon 'The Environmental Perspective in the 1999 Nigerian Constitution' [2004] (38)(1-4) Journal of Constitutional and Parliamentary Studies 54.

R. Land, The Evaluation of Integrated Resource Management (University of Calgany Press Calgary Alberta 1986) 26. Webster's Dictionary - International Edition, (International Publisher's Guide Group, New York 2004) 316. Henry Campbell Black, Black's Law Dictionary, (5 ${ }^{\text {th }}$ ed, St. Paul Minn West Publishing Co. 1979) 479.

Olanrewaju Fagbohun, The Law of Oil Pollution and Environmental Restoration: A Comparative Review, (Odade Publishers, 2010$) 41$. National Environmental Standards and Regulations Enforcement Agency (Establishment) Act No. 25 of 2007 (NESREA Act), S.37. Lawrence Atsegbua, Vincent Akpotaire, and Folarin Dimowo, Environmental Law in Nigeria - Theory and Practice, (Ababa Press Ltd 2003) 3 .

Act No. 25 of 2007.

The National Environmental Standard Regulation and Enforcement Agency (Establishment )Act No 25 of 2007 , s. I.

Section 2 NESREA Act.

Ibid at s. 7 .

Ibid
} 
To enable it perform its functions, the Agency is empowered to purchase or take on lease any interest in land, building or property; build, equip and maintain the offices and premises; prohibit processes and use of equipment or technology that undermine environmental quality; subject to the provisions of the Constitution of the Federal Republic of Nigeria, 1999, and in collaboration with relevant judicial authorities, establish mobile courts to expeditiously dispense cases of violation of environmental regulations; Other than in the oil and gas sector, the Agency is to conduct public investigations on pollution and the degradation of natural resource. In line with its powers, NESREA has, in a bid to improve air quality in Nigeria, banned the importation of two stroke engines in machines such as motorcycles, saw chains and marine outboard motors. ${ }^{1}$ In addition, the Agency has created awareness on several issues pertaining to the environment. For instance, the Agency embarked on public sensitization on air and noise pollution arising particularly from the use of electricity generators. The Agency is canvassing for the use of alternative power sources such as solar energy. They have also canvassed for the planting of trees to absorb the carbon dioxide released into the atmosphere. ${ }^{2}$ In general, the Agency is to do such other things as are necessary for the efficient performance of its functions but it is not to delve into the oil and gas sector. ${ }^{3}$ In addition, the Nigerian government, led by NESREA has embarked on a project geared towards stemming the tide of electronic wastes in the country. ${ }^{4}$

The promulgation of the National Environmental Standards Regulation and Enforcement Agency (Establishment) Act 2007 was a sincere, pragmatic and serious effort towards tackling the issue of environmental protection, preservation and development. As stated by Omaka one thing the new law has been able to achieve is increase in the penalty regime and covers more environment issues. It has also repositioned the Agency created thereunder, for effective performance. How far the operators and managers can actualize the laudable provisions of the law is another question, the government and citizens of Nigeria must however support the Agency in achieving the objectives of the Act. ${ }^{5}$

The National Environmental Standard and Regulations Enforcement Agency Establishment Act 2007 was amended in 2018, by the National Environmental Standard and regulations Enforcement Agency Establishment (Amendment) Act of 2018. Prominent in the said amendment is the insertion of Section 4A which empowers the Agency to arrest without warrant in cases of urgency where the pollution of the environment is immediate or there is imminent threat to life and property, or to prevent the commission of an offence and an application to court for warrant will cause undue delay that may be prejudicial to the maintenance of public order or safety. Also section 41A was inserted extending the benefit or protection of Public Officers Protection Act to the agency and S.32A which forbids the levying of execution against the agency without first obtaining the consent of the Attorney General of the Federal. These sections no doubt are to fortify the powers of the agency and give her confidence in the execution of her duties.

Another major attempt in the protection of the environment arising from the influence of the Constitutional provision is the establishment of the National Oil Spill Detection and Response Agency which was established by virtue of the National Oil Spill Detection and Response Agency (Establishment) Act 2006 (NOSDRA Act). The Agency is a body corporate with perpetual succession ${ }^{6}$. The functions of the Agency include: ${ }^{7}$

a) to be responsible for surveillance and ensure compliance with all existing environmental legislation and the detection of Oil Spills in the petroleum sector;

b) to receive reports of oil spillages and coordinate Oil Spill response activities throughout Nigeria;

c) to coordinate the implementation of National Oil Spill contingency Plan (NOSCP) as may be

formulated, from time to time by the Federal Government;

d) to co-ordinate the implementation of NOSCP for the removal of hazardous substances as may be issued by the Federal Government;

\footnotetext{
These machines have high combustion. The Federal Government has, in addition, banned the importation of the brand of generators popularly referred to as 'I Pass my Neighbor'. These generators are known to cause a higher level of air pollution than the regular power generators. 'FG Bans Importation of Gen Sets' Available at www.vanguardngr.com. Accessed 31 July, 2019.

2 Chidimma C Okeke, 'NESREA Set to Tackle Pollution as Nigeria Ranks World's Most Polluted' accessed 30 July, 2019 available at www.pressreader.com; 'Pollution: Agency Decries Increasing Use of Generators' available at https://guardian.ng $>$ tag $>$ nesrea. Accessed 30 July, 2019.

3 Section 8 NESREA Act.

$4 \quad$ 'Nigeria turns the tide on electronic waste' available at www.unenvironment.org. accessed 31 July, 2019; see also 'At last FG Moves towards Zero Waste Tolerance Level' available at www.nesrea.gov.ng. accessed 31 July, 2019; 'Nigeria: Toxic Waste Ship Still Detained in Lagos' available at https://allafrica.com>stories. Accessed 31 July, 2019.

5 C.A. Omaka, Environmental Regulation in Nigeria (Lions Unique Concepts, Lagos, Nigeria, 2010) 45

6 See Section 1(2) of NOSDRA Act NOSDRA Act SS. $6 \& 7$
} 
e) to ensure the coordination and implementation of NOSCP within Nigeria including within 200 nautical miles from the baseline for which the breath of the territorial waters of Nigeria is measured;

f) to undertake surveillance, reporting, alerting and other response activities as they relate to Oil spillages; g) to encourage regional co-operation among member states of West African sub-region and in the Gulf of Guinea for combating oil spillage in Nigeria's contiguous waters etc.

This Act, though limited to oil activities, is another major breakthrough by the Government in her efforts towards protecting the environment especially in the Niger Delta regions where oil spillage and other oil exploration and exploitation activities have devastated the environment. ${ }^{1}$ NOSDRA is actively involved in the investigation of the recent pipeline explosion in Kom kom community. ${ }^{2}$

\section{Other Statutory Provisions on the Protection of Environment in Nigeria}

Although the issue of environmental protection and preservation is given Constitutional recognition for the first time in the 1999 Constitution, it does not imply that Nigeria never paid any iota of attention on the protection and preservation of the environment. Thus, before the 1999 Constitution environmental protection appears to have sufficiently attracted the attention of the Government of Nigeria. These could be gleaned from the following enactments and regulations namely: ${ }^{3}$

(a) Section 245 and 247 of the Criminal Code; ${ }^{4}$ which makes it an offence for anyone to corrupt the water and makes it less fit for the purpose for which it is ordinarily used;

(b) Oil in Navigable Waters Act, ${ }^{5}$ which makes it an offence for any ship to discharge any oil into the prohibited areas of the sea. This law was made to give effect to the International Convention for the Prevention of Pollution by Oil, 1954;

(c) Oil Pipelines $\mathrm{Act}^{6}$ which prohibits pollution of the environment by any person who procures oil licence during her operations;

(d) Petroleum Act ${ }^{7}$ which empowers the Minister of Petroleum to make regulation for the protection of the environment;

(e) Minerals and Mining Act $^{8}$ empowers the President to make regulations for the prevention of pollution to natural water supply, the disposal of sludge slit and control of sludge channels;

(f) Associated Gas Re-Injection Act $^{9}$ which is geared towards protecting the environment against gas flaring;

(g) Environmental Impact Assessment Act. ${ }^{10}$ The aim of this Act is to ensure that for every project whether private or public its impact on the environment is ascertained especially as it will affect living beings in the environment. This Act was enacted in obedience to United Nations call on countries to access the environmental suitability of every project and infrastructure in human settlement and its ecological consequences;

(h) Harmful Waste (Special Criminal Provisions etc.) Act. ${ }^{11}$ This Act criminalizes any act of unlawful dumping or depositing of harmful waste into the environment;

The functions and powers of the Agency are wide enough to enable it sufficiently and effectively discharge its duties.

'Rivers: NOSDRA makes shocking revelations on Komkom pipeline explosion' available at www.dailypoost.ng. accessed 31 July, 2019 .

3 See Generally, Uwen E. Udok, 'Environmental Degradation in the Niger Delta: A Critique of Existing Laws for Curbing Degradation' [2007] (1) Nigerian Environmental Laws Review 64-76, Edwin Obimma Ezike, 'Liabilities for Environmental Pollution Damage in Nigeria' [2000] (28) JPPL 65-88. CA Omaka, Environmental Regulation in Nigeria (Lions Unique Concepts Lagos Nigeria 2010).

Cap C38 Laws of the Federation of Nigeria (LFN) 2004.

Cap 06 Laws of the Federation of Nigeria (LFN) 2004.

Cap 07 Laws of the Federation of Nigeria (LFN) 2004.

Cap, P1O Laws of the Federation of Nigeria (LFN) 2004

Cap M12 Laws of the Federation of Nigeria (LFN) 2004.

Cap. A25 Laws of the Federation of Nigeria (LFN) 2004.

. Cap. E12 Laws of the Federation of Nigeria (LFN) 2004.

1. Cap. H1 Laws of the Federation of Nigeria (LFN) 2004. 
(i) Federal Environmental Protection Agency Act. ${ }^{1}$ This Act however has been repealed and replaced by a new Act which will be discussed later.

The Federal Environmental Protection Agency Act was the Principal Act regulating the protection of the Environment in Nigeria. The Act was made as a fallout of the dumping of toxic waste in Koko Island in the Present Delta State by an Italian Business Mogul, Gian Franco Raeffeli. ${ }^{2}$ The Act remained in force from 1988 when it was promulgated until 2007 when it was repealed by the National Environmental Standards Regulation and Enforcement Agency (Establishment) Act 2007 (NESREA Act). As stated earlier the 1999 Constitution elevated environmental matters to Constitutional status. This is what is happening in other countries. Both citizens and nations have become conscious of the importance of the environment.

\section{International Perspectives}

As stated earlier, the traditional approach to environmental matters is that environmental protection and economic development are incompatible and cannot co-exist. The developing countries queried the rationale why developed countries and indeed, the international regime on environmental protection demand that their development projects should be environment friendly. ${ }^{3}$ The developing countries found no moral justification why the developed countries that could not adhere to the principles of protecting and preserving the environment during their early stage of development and are at the moment the worst polluters of the environment should suddenly become champions of environment protection. ${ }^{4}$ This attitude has since changed, and both local and international communities have accepted the need to protect the environment through the concept of sustainable development. According to Okon 'It has been realized that development, no matter the avenue through which it is pursued, cannot be sustained without the explicit consideration of its impact on the environment since such impact could derail the processes of development. Similarly, it became clear that a good environment that facilitates a high quality of life could be obtained and sustained only through development that considers environmental concerns. ${ }^{5}$ It can conveniently be asserted that efforts at integrating environment and developmental aims are now universally acknowledged as the modern approach. Against the backdrop of this understanding the UN General Assembly appointed the World Commission on Environment and Development (WCED) to ascertain how environmental protection could be harmonized with economic development. The said commission in her report of 1987 titled 'Our Common Future' (otherwise called Brundtland Report) proposed sustainable development to balance economic development with environmental protection. Earlier enough the United Nations in article 25 of its Charter provides that 'Everyone has the right to a standard of living adequate for the health and wellbeing of himself and of his family including the food, clothing, housing and medical care.' The International Covenant on Economic, Social and Cultural Rights 1966 also provides in Article 12 that the steps to be taken by states parties to the present covenant to achieve the full realization of this right shall include those necessary for:

a. Improvement of all aspect of environmental and industrial aspect of hygiene;

b. The present treatment and control of epidemic, endemic, occupational and other diseases.

The Stockholm Declaration of 1972 provides that state parties have responsibility to ensure that the activities within their jurisdiction and control do not cause damages to the environment of other states or of areas beyond the limits of their national jurisdiction. ${ }^{6}$

The Rio Declaration on Environment and Development adopted at the United Nations Conference on Environment and Development in 1992 which was convened to mark the $20^{\text {th }}$ anniversary of Stockholm Conference on Human Environment in its principle 3 states that "the right to development and environment must be fulfilled so as to equitably meet development and environmental needs of present and future generation" while principles 4 states that in order to achieve sustainable development, environmental protection shall constitute an integral part of the development process and cannot be considered in isolation from it. Sustainable development was defined as development that meets the need of the present without compromising the ability of the future generations to meet their own needs. ${ }^{7}$ Again the Kyoto Protocol to the United Nations Frame Work

Cap. F10 Laws of the Federation of Nigeria (LFN) 2004.

A similar occurrence was recently stalled by NESREA. 'Customs, NESREA repatriates 4 Container load of e-waste' available at www.vanguardngr.com. Accessed 31 July, 2019.

E. E. Okon (n 4) 60 .

Ibid 61 .

Ibid 61

Article 21 Stockholm Declaration 1972

Our Common Future: The World Commission on Environment and Development (1987) 43 
Convention on Climate Change of $11^{\text {th }}$ December 1997 which came into effect in 2005 commits parties to reduce Greenhouse gas emission. This protocol which is the first major international agreement places greater responsibility on developed countries to realize that they are responsible for the current high level of Green House Gas emissions in the environment because of their more than 150 years of industrial activities. This protocol was amended in $8^{\text {th }}$ December, 2012 in Doha Qatar.

At the regional level, the African Charter on Human and Peoples' Rights provides that: 'All peoples shall have the right to a general satisfactory environment favourable to their development.' ${ }^{1}$ This Charter has not only been ratified but have been domesticated by Nigeria, Thus it becomes part of the country's domestic statutes'. ${ }^{2}$ By this domestication, it can be argued that the right of citizens to satisfactory and favourable environment has been crystallized, it is no more a non justiciable directive principles or fundamental objective as provided in Section 20 of the Constitution of the Federal Republic of Nigeria 1999 (as amended).

These International and Regional instruments illustrate the seriousness and importance attached to the protection of the Environment at the international level, since it is obvious that the world cannot talk of sustainable development without safe environment.

\section{Judicial Attitude to the Environmental Objective under the Nigerian Constitution}

The provisions of Section 20 of the Constitution of the Federal Republic of Nigeria 1999 is not justiciable like other provisions of the Fundamental Objectives and Directive Principles of State Policy by virtue of Section 6(6)(c) of the Nigerian Constitution, therefore, a citizen may not successfully maintain personal action on his right to the protection of the environment. However this non justiciability is not sacrosanct as stated by the Supreme Court in the case of Federal Republic of Nigeria v. Anache \& Ors. In Re Chief Olafisoye ${ }^{3}$ that the Chapter could be justiciable if the constitution provides otherwise in another section which makes any of the sections of Chapter II justiciable; or the National Assembly in exercise of its powers makes a law making any item of Chapter II the subject of that law it will be justiciable. The Supreme Court reiterated this position in the recent case of Centre for Oil Pollution Watch v. NNPC ${ }^{4}$ when the Court declared as follows:

In my humble view, the non - justiciability of Section 6 (6) (c) of the Constitution is neither total nor sacrosanct as the subsection provides a leeway by the use of the words 'except as otherwise provided by this Constitution'. This means that if the Constitution otherwise provides in another section, which makes a section or sections of Chapter II justiciable, it will be so interpreted by the courts... The implication of this authoritative pronouncement is that the proper approach to the interpretation of the said chapter should be by the mutual conflation of other provisions of the Constitution with the provisions of Chapter II. This is so because "if the Constitution provides otherwise in another section, which makes a section or sections of Chapter II justiciable, it will be interpreted by the Courts"...

In Oronto Douglas v. Shell Petroleum Development Corporation and 5 Ors $^{5}$ the Federal High Court Sitting in Port Harcourt dismissed the action of the plaintiff brought under the Environmental Impact Assessment Act, on the ground that the plaintiff had no locus and had not suffered any personal injury to justify the action. However, in a later decision, the Federal High Court Benin held that the action of the $1^{\text {st }}$ and $2^{\text {nd }}$ Respondents in continuing the flaring of gas in the course of their oil exploration and exploitation activities in the Applicant's community was a gross violation of the Applicant's constitutionally guaranteed right to life (which includes healthy environment) and dignity of human person. ${ }^{6}$

In the Social and Economic Rights Action Centre \& Anor v. Federal Republic of Nigeria, ${ }^{7}$ a petition by two Non-Government Organizations against the Government of Nigeria alleging inter alia that the government of Nigeria supported Shell Petroleum Development Corporation in environmental degradation of Ogoni Land, acts of state brutality and repression and other acts which they claimed violated their right under the African charter on Human and Peoples Right. This action was brought before the African Commission on Human and Peoples

\section{Art. 24}

See Cap. A9 Laws of the Federation of Nigeria (LFN) Cap. A9 2004) S. 24

(2004) All FWLR (Pt. 186) 1106 at 1153

(2019) 5 NWLR (Pt. 1666) 518 at 569 per Justice Nweze

Suit No. FHC/2SC/573/93 unreported, delivered on 17/2/97 - This case went on appeal to the court of Appeal - see (1999) 2 NWLR (Pt. 591) 466 where the Court of Appeal upheld the appeal brought pursuant to article 24 of the African Charter.

6 Jonah Gbemre v. Shell Petroleum Development Company of Nigeria \& 2 Ors.; Unreported Suit No: FHC/B/CS/53/05 delivered on $14 / 11 / 2005$

7. (2002) 2 CHR 537 or 2001 AHRLR 60 
Right, sitting in Banjul, the Gambia. The commission held among other things that the right to favourable environment under article 16(3) of the African Charter on Human and Peoples Rights obligates the government to desist from directly threatening the health and environment of citizens.

In Attorney General of Lagos State v. Attorney General of the Federation and 35 Ors, ${ }^{1}$ the Supreme Court of Nigeria held that Section 20 of the Constitution does not authorize the Federal Government to legislate on town /urban and regional planning matters, that is within the legislative competence of the state government which makes laws for the physical layout and development of any town or region in the country. However, the Federal Government can legislate on general environmental protection issues.

\section{Concluding Remarks}

Environmental matters should attract the interest and attention of everybody both private and public; government and individuals. Although government is urged to always play both the leading and supportive role, the citizens play a key role in the quest for a healthy environment. However, there seems to be an apparent disregard for the environment by a large section of the Nigerian public. In spite of awareness on the hazards posed by vandalisation of pipelines and other illegal oil refining, these practices persist. This disregard of the environment is born out of several issues ranging from poverty to inadequate performance of functions by relevant government agencies.

A perusal of the laws on environmental issues in Nigeria, reveal that the country has a good legal framework for the protection of the environment. There is however need for everyone to be committed to the idea of sustainable development.

Economic development and environmental protection are intertwined. A good number of actions that have negative impact on the environment are fueled by desire for financial gain whether by industries, states or individuals. The environment cannot be adequately protected where poverty ravages its human inhabitants. It is true that poverty is not the sole cause of environmental degradation, it cannot be ruled out as a factor. The environment would be the least concern of the average man who is ravaged by poverty. While there is need for relevant agencies to do effectively carry out their functions as stipulated in the laws setting them up, there is also need for the government to introduce programs and policies geared towards improving the Nigerian economy and consequently, the lives of persons living in Nigeria. All the organs of government must show concern, sincerity and be pragmatic on issues relating to environment, because the environment is not just one of those fundamental objectives and directive principles, it is life in its totality, from the house where we live to the water we drink, food we eat, cars and aeroplane we use including the leisure we enjoy. There must be a balance between development and protection of the environment. As stated by Emejuru, 'the relationship between the environment and development is now in the process of reassessment. The world has begun to realize that the goals are not mutually exclusive but are, in fact, inter dependent. It is equally clear that the environment is a (scarce) commodity of great value for both present and future generations. Environmental protection is not a cost but an investment in the future.'2 This opinion expressed by Emejuru appears to be in line with the opinion of International Court of Justice recognizing the importance of environmental protection and sustainable development in the case of the Legality of the Threat of Use of Nuclear Weapons wherein the Court stated as follows:

The environment is not an abstraction but represents the living space, the quality of life and the very health of human beings, including generations unborn. The existence of the general obligation of States to ensure that activities within their jurisdiction and control respect the environment of other States or of area beyond national control is now part of the corpus of international law relating to the environment. ${ }^{3}$

From the plethora of opinions it is obvious that the environment is synonymous with man and there can be no existence without the environment, simply put environment is man and man is environment no more, no less. There should be that collective effort to protect and preserve the environment through constitutional and other statutory means both at the domestic and international levels.

(2003) FWLR (Pt. 168) 909 or (2003) 15 NWLR (Pt. 842) 113.

C.T. Emejuru, 'Smarting the Environmental Problems of Niger-Delta by the Multinational Oil Corporations in Nigeria' [2007] (1) Nigerian Environmental Law Review 35-36.

'Legality of Threat of Use of Nuclear Weapons', ICJ Reports (1996) 241 - 242. Also cited by S. Atapattu, 'Recent Trend in International Environmental Law' [1995] (10) Sri Lanka Journal of International Law, Note 25, 53. 